\title{
MAGNA CARTA AND ITS SIGNIFICANT ROLE FOR RULE OF LAW IN THE REPUBLIC OF MACEDONIA
}

DOI: $10.1515 /$ seeur-2015-0012

\begin{abstract}
One of the most important and famous historical documents from the English legal and constitutional legacy is the Magna Carta Libertatum. Signed and sealed in the year 1215 the Magna Carta is further on viewed as the sole inception of the idea of limiting the power of the ruler trough legal rules. That limitation is to be made with legal rules that are binding for everyone, even the monarch. Therefore, the Great Charter is viewed as the first document signed by a monarch with which, the principle of supremacy of the law is set out. That supremacy of the law has been further on developed by eminent scholars and practitioners, eventually leading to the development of the concept of rule of law. Rule of law, as a concept, means that the royal authority (or the executive branch of power) is going to be inferior to the law. However, this concept means a lot more than simply that. Unlike the principle of legal state, the rule of law is closely linked to justice, separation of powers and legal certainty. All of these concepts are actually prerequisites for its existence. That is why each of them is separately examined and elaborated. Furthermore, as one of the most important principles the rule of law had a great influence on the constitutional (and legal) systems around the world. Since the Republic of Macedonia strives to become a democratic state where the rule of law is established and developed it is important to elaborate the influence of this principle in it. Therefore, the research gravitates over the principle of rule of law in the Republic of Macedonia.
\end{abstract}

\section{HISTORICAL SIGNIFICANCE OF THE MAGNA CARTA LIBERTATUM}

Magna Carta Libertatum, the Great Charter of Liberties is one of the most famous documents from the English constitutional and legal legacy. It would be impossible, nowadays, to debate over the modern constitutional principles around the globe and not to mention the Magna Carta. Signed by John Lackland the King of England in 1215, it becomes people's main mechanism for inhibiting unjust rule. It is a fact that the feudalism, as a period in the history of the world, has a widely known deficiency of constitutional rules. Regardless of that, the Magna Carta is perceived as an inception of the idea to limit the power of the rulers. As such it has a great impact on the further development of English constitutionality, and it is the corner - stone of the modern legal systems. Although, it has been often noted that the Magna Carta should, perhaps, not be idealized, being a mere bargain between the "cowardly" King John and the Barons lined up against him (Ibeji, 2011), it is the "spirit" of the document that has incisive effect. That "spirit" of the Charter is what stands behind its success, and it 
exceeds the meaning of the specific clauses set out in the 63 Articles, founding the most important principles - supremacy of the law and government by consent. Therefore, by signing the Magna Carta, King John made an unprecedented move in human history, making the royal authority for the first time a subject of the law, opposite from its previous position where he could simply stay above it and reign freely, having no restraints at all.

It is undisputed between the historians that the Magna Carta is not the first document where ideas for limitation of the royal powers are found. Such ideas are developed even beforehand as Popovska (2011, page no 2) explains. Namely, there is a fragment from Iustinianus Primus' Institutions where it is stated "...cum lege regia que de imperio eius lata est, populous ei et in cum omne suum imperium et potestatem concessit", meaning that the people hold the power (imperium) which is merely delegated to the emperor (Popovska, 2011, page no 2). Additionally, in the year 1100, upon taking the throne King Henry I issued the Coronation Charter in which he promised to restrain from abuse of power (History channel). However, the Magna Carta is often observed as the first document of such sort, due to the serious circumstances in which it has been signed. The conflict with the Pope, the battles in France and the civil war with the barons coerced King John to sign the Charter, and made it seemingly realistic that its clauses are going to be respected (Popovska, 2011, page no 2).

From the signing of the Charter on, the King had a frame in which his authority could be effectuated, a frame holding significant restrictions, and even more importantly - repercussions in case of breach. Namely, a Council of 25 barons has been formed. That Council had the right to decide whether the King breached the Charter, and if it found that he did, they would gain the right to rebel and dethrone him. If limitation of the power of the ruler was something unimaginable beforehand, in 1215 it became near reality. In spite of the fact that, initially, it has not been quite successful the Charter became the very substructure for the limitation of the royal powers, enabling the people to resist the despotic reigning. For that reason, the Charter is often deemed a great success, and is referred to as the cradle of the modern constitutions and the idea of a legal act with a superior strength, lex superior (Skarik, 2006, page no 142). The idea to limit the (beforehand absolute) power of the ruler, although materialized in a very rudimental form, inspired many other theories and, of course, legal acts. Showing that the people, wherever on the globe, are often implacable if abuse of power exists, the Magna Carta was the spark that led to democratic and legal renaissance. Setting a hierarchy, where the will of the ruler is below the law, the Charter outlined the border of the King's authority. The King had no right to arbitrarily enter the private sphere of the citizens (Skarik 2006, page no 238). That way, the idea of supremacy of the law found in the core of the Magna Carta lead to a development of a very significant idea, that is, the rule of law. A number of influential individuals in England reflected on Magna Carta's idea for the supremacy of the law and interpreted it differently. By doing so, each author contributed for to the overall process of development of democratic principles. Showing intrepid attitude, the philosophers in the mid - centuries spoke about the supremacy of the law and the rule of law, demurely creating an idea that is obviously so inherent to the human nature, it has been accepted as fundamental in every modern political and legal system in the world.

Many authors and philosophers have had a significant role when it comes to the constitution of the rule of law principle. As Skarik (2006, page no 238/239) explains, the idea for supremacy of the law was supported by many authors in the mid - centuries, such as Henry de Bracton and Richard Hooker in the beginning, followed by Edward Coke and James Harrington. Although different, their standpoints had one common characteristic. They were dealing with the limitation of the power of the rulers, analyzing the most efficient ways to avert the royal authorities from interfering in the private sphere of individuals, and to respect the law. That way, by broadening the idea for supremacy of the law, these authors incepted the idea for the rule of law.

It is important, however, that the rule of law principle is understood properly. What the term itself suggests is vivid. The law is above the royal will, and every authority should obey it. But, the rule of law principle is not limited simply to the obedience of the royal authority to the legal rules. That is more 
closely linked to another different, yet similar principle, called Rechtsstaat (German) translated as legal state or state of law. As said, this principle deals solely with the obedience of the authorities to the legal rules. The content of those legal rules is irrelevant. In other words, any behavior could be justified if it is sanctioned with legal rules that have been passed in a strict, formal procedure. If the legislator passes a law in the specified procedure it is unimportant what the content of that law is. However this brings some risks. As Grizo, Gelevski, Davitkovski and Pavlovska - Daneva (2008, page no 283) explain, there could be situations where the coalition that holds the power passes laws that are unconstitutional and contradictory to the guaranteed human rights and liberties which protect the public interest. That is why the broader, more extensive principle, which is the rule of law developed. It is deriving from the English legal tradition and the Magna Carta.

Unlike the Rechtsstaat principle, the rule of law deals more with human rights and liberties and the search for justice. Basing their philosophical considerations on the Magna Carta, the philosophers constituted this principle so that unjust rule is never again accepted and welcomed. In that sense, Kambovski (2010, page no 107) explains how the philosopher Francis Bacon made a difference between the just law (law based upon justice and equality), and the formal law (merely called a law despite its unjust nature). Therefore, one could speak about rule of law only if all the laws are just in the way that Bacon explained them. If, on the other hand the laws are unjust, it is irrelevant whether the royal authority obeys them or not. What is of great importance to note is that Bacon and the mid centuries philosophers were not the first who spoke about the link between the law and justice. Even the roman lawyers defined the law as ars boni et aequi (art of the good and just). So the main question arising is what makes a law just, or in other words, which laws are just? The meaning of justice is, indeed, a matter of limitless discussions and debates in the legal theory, which makes it really difficult to find one final definition of it. As people can often see, the concepts that are so easily understood are the hardest to define. One author said we can find a large number of examples for injustice, but we have no idea where to start when giving an answer to the question: what is justice (Kambovski, 2010, page no 190)? Although, many authors have given different definitions of justice, what is certain is that that the concept of justice always holds an idea of the "greater good" in itself. One could speak of justice only if people are equal and each person has an equal chance to compete with the rest in the society. The intervention of the royal and state powers (imperium) in the private sphere of individuals could only be acceptable if its aim is to deliver justice and create equilibrium. Any other arbitral intervention is an abuse of the royal powers and is inadequate to the rule of law principle. Conclusively, it is not enough that the royal authority obeys the laws. The laws must also be just, and only then, there is a rule of law.

It is undeniable that the rule of law, as a concept, may seem perfect as far as discussed on a theoretical level; however, in order for the idea to be materialized there are certain prerequisites that have to be met. The intent to prevent the authority from interfering in the sphere where the intervention is intolerable and uninvited has to be braced with serious mechanisms, enabling it to become reality. Seeking for ways to ensure that the royal powers are not going to be abused, and that the limits are indeed going to be respected, many authors came to the conclusion that it would only be possible so, if the powers are divided/separated. In that sense, it has been highlighted by Montesquieu, one of the most prominent philosophers in France, that in order to prevent the abuse of powers, things should be regulated in such way that one authority controls the other. In one of his most famous books The Spirit of the Laws (French: De l'esprit des lois - 1748) Montesquieu speaks about the separation of the legislative (puissance legislative), executive (puissance executrice des shoses qui dependent du droit des gensl) and the judicial power (puissance executrice des shoses qui dependent du droit civil:puissance de judger). That way Montesquieu constituted the idea for trias politica or the three way, three - parted system. In that system three different bodies shall hold different powers. Namely, a body of elected officials will have the legislative power, another body shall execute the legislation and an independent court will hold the judicial power and control the executor. Separated these three powers will control each other with established mechanisms, so that despotic reign is no longer possible, without due consequences. Holding such limitless capacity for creation of a democratic system in which 
there is going to be rule of law, this theory was accepted and further examined by scholars and authors all over the globe. However, the fact that authors and scholars were additionally developing this idea has simply not been enough for her implementation. Although speaking about highly influential authors, the idea for separation of power could not be properly applied if not translated in legal rules. The first attempt to implement this principle has been noted in the French Declaration of Human and Civic Rights of 26 August 1789. As Shumanovska - Spasovska (2011, page no 74) explains, in Article 16 of that Declaration there is a clause stipulating that if the society has no provisions for guaranteeing human rights or separation of power it has no Constitution. That way, the principle Montesquieu spoke for gained actual legal relevance, although in a very unsophisticated and basic form. Therefore, 1789 was the year when there was a significant turnover, and the year from which the rule of law of which the scholars spoke, was actually possible.

The three - parted system advocated by Montesquieu, has been, however, criticized by other eminent scholars later on. Namely, the critics have shown that the idea Montesquieu spoke of is not flawless. As Shumanovska - Spasovska (2011) shows there were eminent scholars criticizing different aspects of the theory. Some of them were Jean Jacques Rousseau, Hans Kelsen, Bordeau etc. Although their critics were different, they were gravitating over few similar ideas. Some authors noted that there could not be a separation of powers, since the state power is indivisible. The sovereignty of the state is indivisible, wherefore one could not speak for the separation of the powers, since the power is a derivate from that sovereignty. In that sense, Shumanovska - Spasovska (2011, page no 73) shows Bourdeau's idea, that there could not be a separation of powers but purely separation of the functions of the one and indivisible state power. Kelsen, on the other hand, found the idea for the separation of powers is impossible, since there could never be a situation in which one state body can merely create the laws, and another one could simply execute them. None of the state bodies does one function in isolation.

Despite the open criticism that has existed, what has been utterly positive is that none of these authors advocated that there should not be control over the royal (executive) powers. Montesquieu's idea has been confronted on certain aspects, but the significance behind it remained. That significance lies in the conclusion that there could not be rule of law and democracy if there is no control over the executive branch of power, which may be royal authority or a collective body of officials, regardless.

It is vivid that the separation of powers (or separation of functions) is an essential prerequisite for the rule of law. However, as the concept ripened some scholars embraced the standpoint that this is not the only one. In that sense, besides the correspondence (relation) between the state bodies, scholars have spoken about the relation between the citizens and the state also. As Skarik (2011, page no 242) says, the legal certainty is also a necessity when it comes to the rule of law. This scholar explains that the legal certainty depends on the procedural guarantees and legal remedies with which the individuals can protect their own rights. Further on he notes that the procedural guarantees are possibly the most important prerequisite, and that the proclaimed human rights have no actual value if there are no remedies for their protection. Finally, he supports his standpoint with one of the most famous Latin maxims ubi jus ibi remidium (where there is a right, there is a remedy). Explaining all these prerequisites, the scholars around the world developed a logical and perfect concept, which is now almost universally accepted, especially in the states with a high level of democracy (or the ones striving for it).

\section{INFLUENCE OF THE MAGNA CARTA LIBERTATUM FOR THE RULE OF LAW IN THE REPUBLIC OF MACEDONIA AND THE POSITION OF THE PUBLIC ADMINISTRATION}

As a state in the process of development, the Republic of Macedonia strived to create a (legal) system that shall embrace the principles originating (in)directly from the Magna Carta and its spirit. The Constitution of the Republic of Macedonia from 1991 is the lex superior, the legal act on which the 
whole legal system is based upon. Therefore, it is obviously the starting point of the exploration. Unlike the Constitutions deriving from the time when the Republic of Macedonia was a part of the Socialist Federal Republic of Yugoslavia, the Constitution of 1991 is modern and consistent with the democratic principles around the globe. The Preamble of the Constitution (the original one from 1991 and the amended one from 2001) refers to the concept of rule of law, and states that the Republic shall endeavor to establish and develop rule of law and to protect and guarantee human and civil rights and liberties. This indicates, right away, that the Republic of Macedonia accepts the rule of law principle and adopts it, making it a foundation of the whole legal system. Furthermore, the rule of law principle is not only referred to in the Preamble, but it is also exalted as one of the fundamental (core) values of the constitutional order. The Sixth Amendment (2001) enumerates the fundamental values which are:

* Basic freedoms and rights of the individual and citizen, recognized in international law and set down in the Constitution;

* Free expression of national identity, equitable representation of persons belonging to all communities in public bodies at all levels and in other areas of public life;

* Rule of law;

* Division of state powers into legislative, executive and judicial;

* Political pluralism and free, direct and democratic elections;

* Legal protection of property;

* Freedom of the market and entrepreneurship;

* Humanism, social justice and solidarity;

* Local self-government;

* proper urban and rural planning to promote a congenial human environment, as well as ecological protection and development; and

* respect for the generally accepted norms of international law.

Reading what has been stipulated here, a general conclusion follows that the abovementioned principle of rule of law, its prerequisites, and the ideas the Magna Carta incepted centuries ago have had a strong influence on the Macedonian legal system. The elements of the elaborated theories and standpoints are contained in the fundamental values of the constitutional order, setting the Constitution of the Republic of Macedonia among the rest of the modern (western) democratic Constitutions.

\subsection{JUSTICE IN THE REPUBLIC OF MACEDONIA AS A PREREQUISITE FOR THE RULE OF LAW}

The values of the constitutional order deemed as fundamental are, naturally, further developed in the clauses throughout the whole Constitution (1991). The prerequisites for the rule of law principle were elaborated in a certain order; so we are going to keep that order when comparing the constitutional provisions (and the reality in the Republic of Macedonia) with the theoretical considerations. As said, the rule of law principle is closely linked with the existence of justice, or to be specific, just laws. The laws are (and can be) just only when they create equilibrium in the society, giving all persons equal chances, while prohibiting the state to use its powers (imperium) for any reasons other than the restoration of the equilibrium. Justice, understood this way, is possible in the Republic of Macedonia, due to the high number of provisions contained in the Constitution (1991) with which human rights are 
guaranteed and protected. Each provision that guarantees a right limits the power of the state, wherefrom, the state could not interfere in the private sphere of the individuals, unless it is done so arbitrarily and unlawfully. Moreover, some of the provisions do not merely limit the power of the state, but also burden the state with certain obligations. Of course, for justice to exist, the constitutional provisions are not sufficient by themselves, and they have to be further transposed in different laws. On that matter, the legal system in the Republic of Macedonia has to be criticized openly, bearing in mind the flaws that exist. The constant changes of the laws, the collisions between them, the terribly high number of provisions they contain, and the deficiency of a Parliamentary debate confuses the ordinary citizen and makes it laborious to exercise the guaranteed rights. We would like to emphasize, in that sense, that the European Commission in its Progress Report (European Commission, 2013) on the Republic of Macedonia in 2013 stated that the legal system has a weakness related to lengthily procedures, corruption and contract enforcement. Even more vividly, in the Progress Report (European Commission, 2014) of 2014 the Commission stated that the frequent changes of the laws create legal uncertainty. So, perhaps in the Republic of Macedonia justice is a possibility, however, not reality?

\subsection{SEPARATION OF POWERS IN THE REPUBLIC OF MACEDONIA AS A PREREQUISITE FOR THE RULE OF LAW}

Justice, and its existence, is not the only prerequisite for the rule of law. It has been noted that, the only way to prevent the authority from interfering in the private sphere of individuals, is to divide/separate the powers (or functions, as explained above). Therefore, the rule of law in the Republic of Macedonia is depended on the separation of powers. Before explaining the separation of powers it is important to note that, before its independence, the Republic of Macedonia had a system where the state power was concentrated in merely one body, which was the legislative. This means that the new Constitution from 1991 was the first lex superior which inaugurated this principle. From that point on, the efforts to achieve separation of powers started. In order to understand the separation of powers in the Republic of Macedonia we would have to explain the relations between the Government and the President of the Republic, the Assembly, and the Judiciary.

The Assembly (Parliament) is the carrier of the legislative power, which means that it has a centralized and key role. Its legislative power cannot be delegated, nor transmitted to another body, except in cases strictly provided in the Constitution. Since it is consisted of representatives of the citizens the Assembly is the state body/institution where democracy is practiced in a most direct way. As the legislative body in the Republic of Macedonia the Assembly has a number of competences, enumerated in Article 68 of the Constitution, which means the method of numerus clausus has been used. In that Article 68 it has been provided that the Assembly:

* adopts and changes the Constitution;

* adopts laws and gives the authentic interpretation of laws;

* determines public taxes and fees;

* adopts the budget and the balance of payments of the Republic;

* adopts the spatial plan of the Republic;

* ratifies international agreements;

* decides on war and peace;

* makes decisions concerning any changes in the borders of the Republic; 
* makes decisions on association in and disassociation from any form of union or community with other states;

* issues notice of a referendum;

* makes decisions concerning the reserves of the Republic;

* sets up councils;

* elects the Government of the Republic of Macedonia;

* elects judges to the Constitutional Court of the Republic of Macedonia;

* selects, appoints and dismisses other holders of public and other office determined by the Constitution and law;

* carries out political monitoring and supervision of the Government and other holders od public office responsible to the Assembly;

* proclaims amnesties; and

* performs other activities determined by the Constitution.

The Government of the Republic of Macedonia and the President of the Republic carry the executive power. Bearing that in mind, we could conclude that the executive power is two - headed, or separated between the Government and the President. However, in reality, the Government holds a lot greater power than the President. Therefore, it is often noted that the effective executive power is in the hands of the first, rather than the latter. The competences of the Government are also enumerated by the method of numerus clausus and they are:

* determines the policy of carrying out the laws and other regulations of the Assembly and is responsible for their execution;

* proposes laws, the budget of the Republic and other regulations adopted by the Assembly;

* proposes a spatial plan of the Republic;

* proposes decisions concerning the reserves of the Republic and sees to their execution;

* adopts bylaws and other acts for the execution of laws;

* lays down principles on the internal organization and work of the Ministries and other administrative bodies, directing and supervising their work;

* provides appraisals of drafts of laws and other acts submitted to the Assembly by other authorized bodies;

* decides on the recognition of states and governments;

* establishes diplomatic and consular relations with other states;

* makes decisions on opening diplomatic and consular offices abroad;

* proposes the appointment of ambassadors and Representatives of the Republic of Macedonia abroad and appoints chiefs of consular offices;

* proposes State Prosecutor of the Republic of Macedonia following a prior opinion of the Council of Public Prosecutors; 
* appoints and dismisses holders of public and other office determined by the Constitution and laws; and

* performs other duties determined by the Constitution and law.

* The method of numerus clausus is also used when it comes to the competences of the President of the Republic of Macedonia:

* nominates a mandator to constitute the Government of the Republic of Macedonia;

* appoints and dismisses by decree ambassadors and other diplomatic representatives of the Republic of Macedonia abroad;

* accepts the credentials and letters of recall of foreign diplomatic representatives;

* proposes two judges to sit on the Constitutional Court of the Republic of Macedonia;

* Proposes two members of the Judicial Council of the Republic of Macedonia;

* appoints three members to the Security Council of the Republic of Macedonia;

* appoints and dismisses other holders of state and public office determined by the Constitution and the law;

* grants decorations and honours in accordance with the law;

* grants pardons in accordance with the law; and

* performs other duties determined by the Constitution

The Judiciary in the Republic of Macedonia, under the Constitution, is independent and free from external control from the executive branch of power. There are three levels of Courts in Macedonia, Courts of first instance, Appellate Courts, and the Supreme Court. Besides those, there is also an Administrative Court and a Higher Administrative Court. It is highly important to stress that the Constitutional Court is not considered as a part of the Judiciary in Macedonia. The competences of the Courts are further determined in the Law on the Courts (2006), and few other Laws.

From the explained competences of the Assembly, Government, President and Judiciary, a conclusion follows that the Constitution offers mechanisms for checks and balances, so that the separation of powers could be effectuated and exercised. Nevertheless, it is a fact that there are real issues when it comes to the separation of powers, issues resulting with a concentration of the powers mostly in the hands of the executive branch. Those issues are mostly related to the independence of the Judiciary, due to numerous questionable cases, where there are suspicions of influence. Analyzing the decisions of the Courts, and especially the case - law of the European Court of Human Rights, where the number of applications increases rapidly each year (in the year 2014 the European Court of Human Rights received 486 applications as seen in its Press Country Profile from 2015) one could conclude that there is selective justice, huge discrepancy between the judgments themselves, corruption and unpredictability. Furthermore, these same issues have been noted from the European Commission. Therefore, a conclusion would follow that, the separation of these three (branches of) powers is not sufficient in reality, and that the rule of law would not be possible until the Constitutional provisions are not properly respected and implemented.

It is vivid that, under the Constitution, the Republic of Macedonia has a tripartite system. In other words, the three - way system has been accepted and implemented. However, the separation of three (branches of) powers is simply not enough for there to be a rule of law. The rule of law would not be possible anyhow, if the public administration is not fully independent and free from any kind of pressure. This 
simply means that the rule of law would only be possible if the Administrative bodies exercise their competences under the law, regardless of the will of the political leaders. Namely, if the political majority can influence the work of the public administration, then, the entire concept of rule of law falls behind and remains just an idea which would never be implemented. It is difficult to stress how important the independence of the administration is, being a necessity for the rule of law. Analyzing the relationship between the administration and the Government (and President), the Assembly and the Judiciary we shall find out whether it is independent or not, whether the rule of law in the Republic of Macedonia is possible or not.

As can be noted, the relationship between the Assembly (Parliament) and the public administration is indirect. The Assembly has an indirect influence when it comes to the administration, bearing in mind that it holds the legislative power. Namely, the different laws that the Assembly passes determine the structure, the position and the competences of the public administration. On the other hand the administration provides expertise for the members of the Assembly, and it should do so in an effective and professional way.

Much more important than the relationship between the public administration and the Assembly is the one between it and the Government. Furthermore, this relationship often brings about confusions and ambiguities, since it is often difficult to draw the line between the Administration as a constant, professional and nonpolitical part of the executive branch of power and the Government as a political body. In that sense it would be best to sharpen the distinction between the administration and the Government with an explanation of their competences. The Government, as a political body, makes plans and foresees situations, while the administration merely effectuates the political decisions. The Government has coordinative, control, and directional competences that are exercised over the administration. Therefore, it is certain that the administration is, in fact, inferior to the Government. It is difficult, when such inferiority exists, to achieve independence of the administration. Regardless of the fact that the legislation has maybe improved, the real situation in the Republic of Macedonia has been noted as seriously concerning, especially when it comes to the independence of the administration from the Government. Following the progress of the Republic of Macedonia the European Commission in its Report from 2014 stated that the politicization of the administration is yet a serious concern, and that there are serious breaches when it comes to the principles of transparency, accountability and merit. Furthermore, the European Commission (2014) elaborates that the public administration remains fragmented and subject to political influence, regardless of the legislation. Accountability, transparency and merit have to be improved. A conclusion would follow that, regardless of the Constitution and the Laws in the Republic of Macedonia, the Government still has a great influence on the work of the public administration, something from which the ordinary citizens suffers, while the whole state is prevented from progression.

Finally, the Judiciary and the public administration are separated and they have organizational and functional independence. However, the Republic of Macedonia has an Administrative court, specialized for administrative disputes, arising between the natural or legal persons and the administrative organs/bodies that can bring a concrete administrative act. That way the Administrative court has a great influence on the work of the public administration.

Republic of Macedonia has made significant efforts to implement separation of powers, and in line with that, to enable the public administration (as a part of the executive branch) to fulfill its tasks under the laws. However, many issues remain and are yet to be intercepted. 


\subsection{LEGAL CERTAINTY IN THE REPUBLIC OF MACEDONIA AS A PREREQUISITE FOR THE RULE OF LAW}

Justice and separation of powers are not, as elaborated, the only conditions for the rule of law. Closely linked, yet different is the concept of legal certainty. If justice means that the there should be human rights and liberties with which equilibrium in the society is reached, then, the legal certainty means that there have to be legal remedies and procedural guarantees for the protection of those rights and liberties. Also, the concept of legal certainty deals with predictability. Namely, if a country strives to accomplish rule of law it would have to enable predictable life for its citizens. Each citizen should be able to predict whether his/her actions would bring about consequences under the law or not, which means that there is no room for selective justice, corruption, and inequality. Furthermore, each citizen should be able to use the legal remedies and procedural guarantees so that he/she protects his/her rights and liberties whenever they are jeopardized and infringed.

One of the biggest problems the Republic of Macedonia faces is, actually, the legal uncertainty. The high number of changes in the laws, the frequent usage of shortened procedure in the Parliament, the collisions between the laws and the problems regarding their implementation make the life of the citizen unpredictable and create uncertainty. For example, as seen from the Report for the work of the Assembly of the Republic of Macedonia for the period of 10.05.2014 to 31.12.2014 (Assembly of Republic of Macedonia, 2014) the Assembly (Parliament) passed 155 new laws in just few months, which is definitely a shocking number, bearing in mind that the Assembly should be an oasis for debate, clash of opinions and standpoints. In the period preceding this one from 01.01.2014 to 05.03.2014 the Assembly passed 186 laws (Assembly of the Republic of Macedonia, 2014). Furthermore, what is even more problematic is that in both periods, most of the laws were passed in a shortened procedure, which should be reserved only for specific situations where time is of the essence. All together, from 2011 to 2014 the Assembly passed 793 laws as it can be seen from the Report for the work of the Assembly of the Republic of Macedonia from 25.06.2011 to 05.03.2014 (Assembly of Republic of Macedonia, 2014). The main question arising is how would the ordinary citizen with no legal education (and even with such education) be able to follow all these frequent changes, and be aware for his/her rights and legal guarantees? That is why, it is often noted in the theory as well as in practice that in the Republic of Macedonia there is an absolute lack of legal certainty, which is possibly the most serious issue, causing numerous issues in the every - day life in the Macedonian society.

\section{CONCLUSION}

What can be concluded is that, in the Republic of Macedonia, the prerequisites for the rule of law are formally met. Namely, there are numerous provisions in the Constitution that guarantee human rights. The legal frame for separation of powers is complete, and the legal certainty is often noted as a great value. Issues, on the other hand arise when these principles should be implemented. There are a lot of indicators for the lack of capacity to implement the rule of law, and furthermore, there is a lack of political will to do so as well. Of course, it is not only the will of the politicians as individuals that contributes. The overall political culture, the behavior of the political parties and the electoral model are factors on which the rule of law is depended. In that sense, for the rule of law to exist, we find that it would be necessary to:

* Strengthen the effective control over the executive (branch of) power, and the public administration. So, could the right solution be professionalization of the legislative, which means that the Inquiry Commissions in the Assembly should function properly? In other words, if the Inquiry Commissions in the Assembly do their tasks properly, then, it would be possible to hold the politicians and the carriers of public functions liable for their behavior. As some eminent scholars from the Republic of Macedonia explain (Grizo, Gelevski, Davitkovski, 
Pavlovska - Daneva, 2011, page no 228) the Inquiry Commissions are constituted by the Assembly itself and their members are the Parliamentarians. When the Inquiry Commissions ask for any information all the administrative bodies, as well as the individuals are obliged to submit the requested information. As these authors further explain, the Inquiry Commissions are a strong mechanism for parliamentarian control in France, as well as in the United Kingdom. Furthermore, professor Kitanoski (1995, page no 193) also finds that these Commissions have a significant number of advantages which enables them to have control over the Government. Besides the Inquiry Commissions, the Legislative Commissions are also highly important as well. Nevertheless, even if deemed very professional and specialized they still do not posses information on their own (original information). Therefore, they still have to use the information they get from the bureaucratic administration, which is, again, an issue. Finally, the experts from practice and the theoreticians should be able to participate in the work of the Assembly, so that they can contribute to its professionalism (Kitanoski, 1995, page no 193).

* Additional efforts should be taken so that the citizens participate in the process of policy creation.

* The Courts should be constantly strengthening. Whenever the judicial decisions are not enforced there should be sanctions. Especially when the public administration does not enforce the judicial decisions from the Administrative and the Higher Administrative Court there has to be liability.

* As already stated above, the Republic of Macedonia should lean towards the principle of rule of law and distance itself from the Rechtsstaat principle. This is due to the fact that the Parliaments are the key actors when it comes to the implementation of the democratic principles and the protection of the citizens. That is why they have to be cautious when passing the laws. Of course, what are the benefits from the law when the law is corrupt (Lilic, Kunic, Dimitrijevic, Markovic, 1999, page no 9).

\section{SUMMARY}

To summarize, Magna Carta Libertatum from 1215 has had a significant role when it comes to the development of the modern principles accepted and implemented in the democratic states. One of the most important principles deriving from the Charter is the principle of rule of law. As state striving to become democratic, the Republic of Macedonia has been putting efforts to establish and develop the principles deriving originally from the "spirit" of the Magna Carta. Therefore, it could definitely be concluded that the Charter had a great influence on the Macedonian constitutional and legal system. However, it cannot be argued that there are not numerous problems that are yet to be intercepted and dealt with. What is utterly important is that, in the process of development the Republic of Macedonia has to gravitate over the "spirit" of the Charter even though written centuries ago, so that is succeeds in its aims. It is a fact that the Republic of Macedonia shall face many obstacles on its path towards the rule of law. However, it is important to stress that the key reforms (unlike the seeming/artificial ones) do take time and energy, but they always bring about a great result.

\section{WORK CITED}

\section{BOOKS:}

Grizo, N., Gelevski, S., Davitkovski, B., Pavlovska - Daneva, A. (2011). Administrativno pravo (2 ${ }^{\text {nd }}$ ed.). Skopje: Iustinianus Primus Faculty of Law. 
Kambovski, V. (2010). Filozofija na pravoto. Skopje: Makedonska akademija za naukite i umetnostite.

Kitanovski, L. (1995). Podelba na vlasta. Skopje

Lilic, S., Kunic, P., Dimitrijevic, P., Markovic, M. (1999) Upravno pravo, Savremena administracija. Belgrade.

Popovska, B. (2011). Istorija na pravoto (part 3). Skopje: Iustinianus Primus Faculty of Law, 2 - ri Avgust - Stip.

Skarik, S. (2006). Ustavno pravo. Skopje: Matica Makedonska

\section{OTHER PRINT SOURCES:}

Shumanovska - Spasovska, I. (2011). Drzavnata uprava vo sistemot na podelba na vlasta (Unpublished doctoral dissertation). Iustinianus Primus Faculty of Law, Skopje.

\section{ELECTRONIC SOURCES (WEB PUBLICATIONS):}

Newspaper Article

Ibeji, M. (2011, February 17). King John and the Magna Carta. BBC. Retrieved from:

http://www.bbc.co.uk/history/british/middle_ages/magna_01.shtml

Online Encyclopedia

Magna Carta (n.d.) In History Online. Retrieved from http://www.history.com/topics/britishhistory/magna-carta

\section{EU PUBLICATIONS:}

European Union, European Commission (2014) Summary of findings of the 2014 Progress Report on the former Yugoslav Republic of Macedonia. Retrieved from

http://ec.europa.eu/enlargement/pdf/key_documents/2014/20141008-the-former-yugoslav-republicof-macedonia-progress-report_en.pdf

European Union, European Commission. (2013). The Former Yugoslav Republic of Macedonia 2013 Progress Report. Retrieved from

http://ec.europa.eu/enlargement/pdf/key_documents/2013/package/mk_rapport_2013.pdf

\section{PUBLICATIONS OF COUNCIL OF EUROPE:}

Council of Europe, European Court of Human Rights (2015) The Former Yugoslav Republic of Macedonia. Press Country Profile. Retrieved from

http://www.echr.coe.int/Documents/CP_The_former_Yugoslav_Republic_of_Macedonia_ENG.pdf 


\section{PUBLICATIONS OF THE ASSEMBLY OF REPUBLIC OF MACEDONIA:}

Assembly of Republic of Macedonia. (2014). Report for the work of the Assembly of the Republic of Macedonia for the period of 10.05.2014 to 31.12.2014. Skopje: Assembly of the Republic of Macedonia

Assembly of Republic of Macedonia. (2014). Report for the work of the Assembly of the Republic of Macedonia for the period of 01.01.2014 to 05.03.2014. Skopje: Assembly of the Republic of Macedonia

Assembly of Republic of Macedonia. (2014),. Report for the work of the Assembly of the Republic of Macedonia for the period of25.06.2011 to 05.03.2014. Skopje: Assembly of the Republic of Macedonia

\section{PARLIAMENTARY AND LEGAL MATERIAL:}

Amendment IV to Amendment XVIII of the Constitution of the Republic of Macedonia (2001)

Amendment XX to Amendment XXX of the Constitution of the Republic of Macedonia (2005)

Constitution of the Republic of Macedonia (1991)

Law on the Courts (2006) 